\title{
Soluble nutrient effects on microbial communities and mosquito production in Ochlerotatus triseriatus habitats
}

\author{
Michael G. Kaufman ${ }^{1,3, *}$, Wendy Goodfriend ${ }^{1}$, Amy Kohler-Garrigan ${ }^{2}$, \\ Edward D. Walker ${ }^{3}$, Michael J. Klug ${ }^{1}$ \\ ${ }^{1}$ W. K. Kellogg Biological Station, Hickory Corners, Michigan 49060, USA \\ ${ }^{2}$ Biology Dept., Depauw University, Newcastle, Indiana 46135, USA \\ ${ }^{3}$ Entomology Dept., Michigan State University, E. Lansing, Michigan 48824, USA
}

\begin{abstract}
We investigated the effects of soluble nutrient inputs into larval habitats of Ochlerotatus triseriatus (Diptera: Culicidae) on microbial components and mosquito production using laboratory and field microcosm experiments. Labile carbon, added as glucose, was the most consistent stimulus of bacterial production as measured by leucine incorporation rates. In laboratory experiments, glucose, but not nitrate or phosphate, stimulated bacterial production in natural treehole water samples; however, glucose in combination with nitrate and phosphate was necessary to stimulate bacterial production on laboratory microcosm leaf surfaces. Field microcosm experiments were then conducted in which the nutrient combination was added periodically during larval development. In the first experiment, nutrients were added weekly or not at all in a $2 \times 2$ factorial design with larval presence or absence. Larval grazing effects on bacterial abundance and production, protozoan and rotifer abundance and biovolume, protozoan cyst abundance, and leaf fungal biomass as measured by ergosterol content, were much more pronounced than any nutrient effects. However, nutrient additions enhanced mosquito survival and affected leaf surface bacterial production. In separate experiments, weekly additions of nutrients at twice the initial concentrations enhanced mosquito production compared to $1 / 2$ initial nutrient concentrations. Additionally, supplementation of nutrients at initial levels, but on successive days during the second week of larval development, enhanced mosquito production relative to additions during the first and third weeks of larval development. Our results show that microbial communities in larval habitats are more likely to be limited by top-down larval feeding effects than bottom-up soluble nutrient inputs; however, mosquito production can be enhanced through soluble nutrient stimulation of microbial growth and the timing of that stimulation.
\end{abstract}

KEY WORDS: Mosquito larvae $\cdot$ Bacterial productivity $\cdot$ Protozoan cysts $\cdot$ Ergosterol $\cdot$ Treehole · Food webs $\cdot$ Labile carbon

\section{INTRODUCTION}

Approximately $40 \%$ of mosquito species are 'container-breeders'. Larvae of these species develop in small (ca. 0.01 to $5 \mathrm{l}$ ) natural or artificial habitats that are periodically filled with rainwater or plant exudate.

*E-mail: kaufman@kbs.msu.edu
Ochlerotatus triseriatus (until recently, Aedes triseriatus, Reinert 2000) is a typical example and can be found in treeholes and discarded tires throughout eastern North America. In the northern parts of its range, $O$. triseriatus is normally the top-level consumer and free from predation in its larval habitats. Although macroinvertebrate community dynamics of treeholes and other container habitats have been 
quantified (Kitching 2001), studies at the microbial level and those that integrate microbial processes with macroinvertebrates have been very limited. This is in spite of the fact that the dominant ecosystem processes in container habitats are allochthonous input and heterotrophic processing of organic matter by microorganisms (Kitching 2001). In treeholes, leaf material and stemflow (rainwater running down branches and trunks of the tree) are known to be important system inputs (Carpenter 1982, Walker et al. 1991, Kitching 2001). Many studies have examined the impact of leaf material on the growth of $O$. triseriatus and similar species (e.g. Carpenter 1983, Walker \& Merritt 1988, Leonard \& Juliano 1995, Walker et al. 1997, Yanoviak, 1999) and have led to modeled estimates of mosquito production based upon leaf material quantity and quality and larval densities (Carpenter 1984, Walker et al. 1997). Other studies have examined the potential nutrient contributions from stemflow (Carpenter 1982, Walker et al. 1991, Kaufman et al. 1999) on mosquito production. However, leaf material and stemflow inputs are only indirect sources of larval nutrition because these inputs are first incorporated into microbial biomass or modified by microbial activity.

The few studies that have addressed microbial populations in treeholes (Washburn et al. 1988, Walker et al. 1991, Paradise \& Dunson 1998, Kaufman et al. 1999, 2001, Eisenberg et al. 2000) have generally provided evidence for strong larval control. Except for temporary reduction of water column bacterial populations through dilution (Walker et al. 1991), stemflow effects are thought to be minor compared to larval effects (Kaufman et al. 1999). Nonetheless, stemflow can enhance mosquito production (Carpenter 1982, Walker et al. 1991). The mechanisms of this enhancement, nutrient addition versus flushing out of toxic or inhibitory metabolites, are not yet known.

Because larval or 'top-down' control of microbial dynamics in container habitats is well-established (Addicot 1974, Cochran-Stafira \& von Ende 1998, Paradise \& Dunson 1998, Kaufman et al. 1999, 2001, Eisenberg et al. 2000), we have begun to examine other constraints on microbial food webs in Ochlerotatus triseriatus habitats. Heterotrophic microbial production can often be resource-limited by labile carbon substrates and/or by key inorganic nutrients such as nitrogen and phosphorus in aquatic systems (Wetzel 1995, Pace \& Cole 1996). While treehole systems are generally rich in organic material and available forms of nitrogen and phosphorus (Walker et al. 1991), much of the carbon is in the form of refractory substances such as tannins and humic material (Mercer \& Anderson 1994). Therefore, carbon quality is likely the primary limit on microbial production in these habitats. Because particulates (e.g. leaf material) must first enter the dissolved pool for uptake by decomposer microorganisms, additions of nutrients as particulates or as soluble forms (e.g. stemflow) should impact the food web in a similar manner. Previous studies have suggested the importance of soluble input from leaf material and stemflow in determining larval development success (Carpenter 1982, Walker et al. 1997).

How nutrient stimulation of basal food resources (e.g. bacteria) in treehole food webs ultimately affects mosquito production is a complex question because of the larvae's generalist feeding habits. First, larvae simultaneously utilize basal bacterial and intermediate protozoan trophic levels. Second, they feed by filtering water column microorganisms and by browsing microorganisms associated with leaf and container surfaces (Walker \& Merritt 1991). These feeding modes may change in relative intensity depending on larval stage and food resource availability (Juliano \& Reminger 1992, Eisenberg et al. 2000). Models of trophic cascades do not often address simultaneous consumption of primary and secondary production by a top-level consumer, particularly as it relates to heterotrophic microbial components (Porter 1996, Cochran-Stafira \& von Ende 1998). Additionally, the models rarely address issues of resources being partitioned into distinct spatial and nutritional categories (Leibold et al. 1997).

In this study, we examined soluble nutrient effects on bacterial production in simulated treehole habitats and the subsequent impact on microbial components (bacteria, fungi, protozoans, meiofauna) and larval development. After determining primary limiting nutrients, we examined the effects of stimulating bacterial production on microbial dynamics with and without larvae present. Because any impact of increased bacterial production might vary with leaf decay dynamics, or larval size and nutritional demands, we also varied the amounts and timing of nutrient additions to determine those effects on mosquito production. A trophic cascade hypothesis model would predict that nutrient additions would increase the biomass/growth rates of alternate trophic levels. Because Ochlerotatus triseriatus larvae feed indiscriminately on all lower trophic levels, we predicted that stimulation of a basal trophic level (bacteria) with nutrients would result in the increase of only the top consumer/predator level. Further, because larval grazing pressure on surfaceassociated microorganisms appears to be different than on planktonic microorganisms (Kaufman et al. 2001), we also predicted that the effects of nutrients would interact with larval presence and elicit different microbial responses in the water column compared to the leaf substrate. 


\section{MATERIALS AND METHODS}

Laboratory Expt 1. This experiment was designed to identify which nutrient class, labile DOC (glucose) or inorganic (combination of $\mathrm{N}, \mathrm{P}$, and $\mathrm{S}$ ), limits bacteria in simulated habitats, and if there are interactions of the nutrients with larval presence. Microcosms for individual larvae were $20 \mathrm{ml}$ glass scintillation vials with one $22 \mathrm{~mm}$ diameter leaf disc cut from senescent American beech Fagus americana leaves, $6 \mathrm{ml}$ of deionized water, and $100 \mu \mathrm{l}$ of treehole inoculum (Kaufman et al. 2001). After several days of pre-conditioning at $20^{\circ} \mathrm{C}$ in the dark, individual 4th instar Ochlerotatus triseriatus larva were added randomly to $1 / 2$ of the microcosms. After $4 \mathrm{~d}$ incubation at $20^{\circ} \mathrm{C}$, nutrients were added as one of the 4 following treatments: inorganic mix $\left(=\mathrm{KNO}_{3}\right.$ at $5 \mathrm{ppm} \mathrm{N}$ final concentration, plus $\mathrm{Na}_{2} \mathrm{PO}_{4}$ at $0.5 \mathrm{ppm} \mathrm{P}$ final concentration, plus $\mathrm{Na}_{2} \mathrm{SO}_{4}$ at $5 \mathrm{ppm} \mathrm{S}$ final concentration); glucose at $20 \mathrm{ppm}$ final concentration; combination (= inorganic mix plus glucose at concentrations listed above); or control (= an equivalent quantity of de-ionized water). These quantities reflect concentrations of inorganic ions and soluble carbohydrate found in stemflow (Carpenter 1982, Kaufman et al. 1999). Twenty-four hours after nutrient additions, microcosms from each treatment group were randomly selected and processed as described below for bacterial abundance and production measurements. Because these procedures involve destructive sampling of water column and leaf discs, separate microcosms were used for abundance and production measurements.

Laboratory Expt 2. This experiment was designed to identify which nutrient, labile DOC, nitrate or phosphate, limited bacterial production in natural treehole water. Water samples from approximately $1 \mathrm{~cm}$ beneath the surface were collected from treeholes near the main campus of Michigan State (Ingham, E. Lansing, MI) and returned to the lab on ice. All sampled treeholes contained thriving populations of Ochlerotatus triseriatus larvae. Water from each treehole was subdivided into five $2 \mathrm{ml}$ aliquots. Each aliquot then received one of the following treatments: $\mathrm{KNO}_{3}$ at 5 ppm $\mathrm{N}$ final concentration; $\mathrm{Na}_{2} \mathrm{PO}_{4}$ at $0.5 \mathrm{ppm} \mathrm{P}$ final concentration; glucose at $20 \mathrm{ppm}$ glucose final concentration $_{\text {; }}$ combination (= nitrate plus phosphate plus glucose in concentrations listed above); or control (= an equivalent quantity of de-ionized water). Twenty four hours after treatment, the samples were processed for bacterial production measurements as described below.

Field Expt 1. This experiment was designed to examine nutrient and larval impacts on microbial biomass. We chose to place microcosms in the field to better approximate fluctuating temperature regimes experi- enced by natural larval populations and to allow destructive sampling for microbial components. Microcosms were constructed as described by Walker et al. (1991) and consisted of sections of PVC (3" inner diameter $[\sim 7.6 \mathrm{~cm}], 6$ "length $[\sim 15.2 \mathrm{~cm}])$ pipe sealed at one end and wrapped with $1 / 2 "$ [ $1.3 \mathrm{~cm}]$ foam pipe insulation. Each microcosm initially received $1 \mathrm{~g}$ (dry weight) senescent white oak Quercus alba leaves that had been collected from a single tree prior to abscission (in March), $300 \mathrm{ml}$ de-ionized water, and an initial addition of inorganic nutrients $(\mathrm{N}, \mathrm{P}, \mathrm{S})$ and $3 \mathrm{ml}$ of a composite treehole inoculum (Kaufman et al. 2001). Initial nutrient additions to all microcosms were at concentrations designed to mimic stemflow input (see above). The tops were covered with an aluminum window screen attached with plastic cable ties. Slots were cut in the screen to allow addition of larvae and nutrients, and to allow collection of adults. In early June 1998, after $1 \mathrm{wk}$ of pre-conditioning in the lab at ambient temperature, the microcosms were secured to trees in a woodlot at the Kellogg Biological Station (Kalamazoo, MI) in groups of 4 per tree using pipe strap around the trunk and plastic cable ties to attach the microcosms to the strap. Microcosms were placed on the northern side of each tree, approximately $0.5 \mathrm{~m}$ above ground level and covered with coarse mesh shade cloth to reduce light penetration. Chicken wire was then secured around each tree base to exclude raccoons.

Larvae and nutrients were added to the microcosms in a $2 \times 2$ factorial design with each tree as a block. Each of the 4 microcosms per tree received a randomly assigned treatment of L+ (larvae present), L- (larvae absent), N+ (nutrients added), or $\mathrm{N}-$ (no additional nutrients). $\mathrm{L}+$ treatments received 40 first instar larvae $2 \mathrm{~d}$ after the microcosms were secured to trees. Those designated as $\mathrm{N}+$ received nutrients 4,11 , and $18 \mathrm{~d}$ after larval additions. Concurrently, an equivalent quantity of de-ionized water was added to $\mathrm{N}$ - treatments. Nutrient additions were the same as the 'combination' treatment described for Laboratory Expt 1. Nutrients were added in quantities calculated to provide the final concentrations described above, assuming a volume of $300 \mathrm{ml}$. No adjustments were made for accumulation of nutrients from previous additions, or for water volume changes in the microcosms during the experiment.

Because analyses required destructive sampling of microcosms, 18 trees were used for this experiment, allowing 6 replicates of each treatment on each of 3 sampling days. Two days after each nutrient addition, microcosms were removed from 6 randomly selected trees and kept in coolers for transport to the lab and subsequent processing. To process each microcosm, the entire water column was poured through a $100 \mu \mathrm{M}$ 
mesh nylon screen into a beaker. Any larvae and pupae were then removed from the screen and frozen. Subsamples of the water were then preserved for counts of bacteria and protozoans, transferred to vials for bacterial production measurements, or placed in vials to be frozen for organic compound analyses (see below). All leaf material was removed, examined for larvae and pupae, and then subsampled with a $17 \mathrm{~mm}$ diameter cork borer for bacterial abundance and production, fungal biomass, and leaf dry mass (Kaufman et al. 2001).

Bacterial abundance: Ten ml water samples were preserved with $10 \%$ formalin and refrigerated until staining with DAPI (Porter \& Feig 1980) and enumerating as previously described (Kaufman et al. 2001). Leaf discs for bacterial counts (2 per microcosm) were preserved in filter-sterilized, buffered formalin and refrigerated. Leaf-associated bacteria were enumerated with DAPI staining as above after dislodgment with sonication (Kaufman et al. 2001).

Bacterial production: Bacterial production was estimated with the ${ }^{3} \mathrm{H}$-leucine incorporation method (Kirchman 2001). All samples were incubated for $30 \mathrm{~min}$ at $20^{\circ} \mathrm{C}$ in the dark. We employed the microcentrifuge tube version of this technique (Smith \& Azam 1992, Kirchman 2001). Water samples were incubated in $2 \mathrm{ml}$ microcentrifuge tubes. Leaf discs (2 per microcosm) were incubated in glass scintillation vials with filter-sterilized water from their corresponding microcosm. Reactions were stopped with concentrated trichloroacetate (final concentration 5\%, v:v). Water samples were processed directly in their incubation tubes, while leaf discs were first sonicated (Kaufman et al. 2001). The leaf sonicates and 2 subsequent rinses were then transferred to microcentrifuge tubes for quantitation of labeled protein in the same manner as water column samples.

Protozoan and rotifer abundance and biovolume: Water samples were preserved and stained with $1 \%$ Lugol's solution (Wetzel \& Likens 1991) and refrigerated. After cells were concentrated in settling chambers, they were classified and counted using inverted light microscopy. Protozoans and microeukaryotes were categorized into the following general groups: large and small circular flagellates, ovoid flagellates, large or small ciliates, large or small cysts, rotifers, and other (unidentified). Biovolumes were determined by measuring the length and width of representative samples of each group (n ranged from 50 to 200 for each category) and calculating volumes based upon simple morphology (Wetzel \& Likens 1991).

Fungal biomass in leaf material: Fungal biomass was estimated from the ergosterol content of leaf subsamples (Newell \& Bärlocher 1993, Suberkropp \& Weyers 1996). Two leaf discs from each microcosm were preserved in 100\% HPLC-grade methanol and refrigerated in the dark. Ergosterol was extracted and quantified as described previously (Kaufman et al. 2001). Two additional leaf discs were removed from each microcosm and dried for determination of leaf disc mass.

Mosquito biomass: Larvae and pupae were counted and numbers of each instar determined prior to freezing. All larvae from each microcosm were frozen en masse as were all pupae. Adults were frozen and stored individually in microcentrifuge tubes. All mosquitoes were then lyophilized and stored desiccated until weighed. Because all microcosms received the same initial number of larvae, survival was defined and analyzed as the total number of living mosquitoes (larvae, pupae, or adults) recovered from each microcosm at each time period.

Field Expt 2. Microcosms identical to those described above were placed on trees (4 per tree) in the same woodlot as in Field Expt 1 and each was randomly assigned one of 2 nutrient treatments for a total of 8 replicate microcosms per nutrient treatment. Nutrients were added at $1 / 2 \times$ and $2 \times$ the levels in Field Expt 1 on Days 4,11, and 18 after addition of 401 st instar larvae. In this experiment, adults were collected every 1 or $2 \mathrm{~d}$ from the time of first noticeable emergence to $40 \mathrm{~d}$ past the day of larval additions. On Day 40 , microcosms were dismantled to collect and freeze remaining larvae and pupae. This experiment was initiated 1 wk later than Field Expt 1.

Field Expt 3. As above, microcosms were attached to trees in the woodlot used for Field Expt 1. Microcosms were attached to each tree ( 3 per tree) and each was randomly assigned one of 3 nutrient treatments for an initial total of 8 replicates per treatment. Nutrients were added at the same concentration as Field Expt 1, but either on 3 consecutive days during the first week (Early), the second week (Middle), or the third week (Late) after larval addition. This experiment was conducted concurrently with Field Expt 2.

Statistics: We employed multivariate and multiple univariate analyses for all data sets from Laboratory Expt 1 and Field Expts 1, 2, and 3. Laboratory Expt 2 was analyzed as a standard 1-way ANOVA. For the factorial design in Laboratory Expt 1, data were first analyzed with MANOVA (SAS Institute) and each variable was then analyzed with univariate hypothesis test techniques (Procedure General Linear Model; SAS). Microbial variables were grouped into water column and leaf categories based on previous results (Kaufman et al. 1999, 2001) and our initial hypotheses, suggesting that water and leaf microbial communities may respond differently to the treatment combinations.

Mosquito production parameters in Field Expt 1 were treated as a separate group because they were 


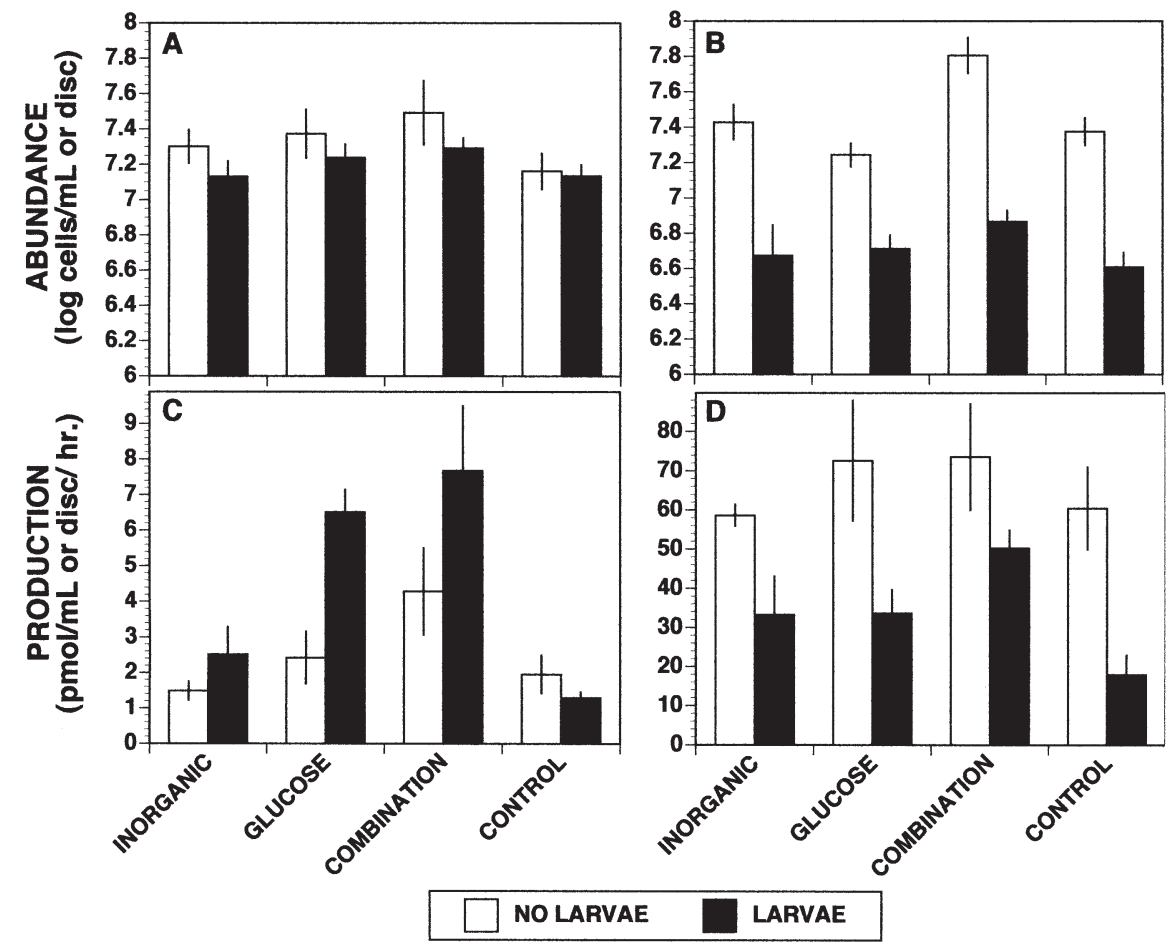

Fig. 1. Bacterial abundance (direct microscopic counts) and production (leucine incorporation rates) responses to larvae and soluble nutrient additions in Laboratory Expt 1. $(A, C)$ Water column; $(B, D)$ leaf surface. Combination = glucose plus inorganics. Control $=$ de-ionized water. Values are mean $\pm \mathrm{SE}, \mathrm{n}=6$ to 8

not components of the full $2 \times 2$ factorial design and also may have responded differently to water column and leaf microbial dynamics. Because production of adults was limited by the duration of the Field Expt 1, we analyzed only total biomass (sum of all recovered stages) and survival. Production of adult females in Field Expts 2 and 3 was also potentially limited by the duration of the experiments and we analyzed total adult numbers and biomass instead of separate male and female components.

The models for Field Expts 1, 2, and 3 included the random block effect of tree, nested within time for Field Expt 1, and thus were a mixed model analysis. Block effects were not significant in any test and therefore are not reported in the results. Although we report results from SAS Proc GLM with mixed model hypothesis tests, we also used SAS Proc Mix. Conclusions (i.e. significant effects) were identical with both procedures. When necessary, data were transformed $[\log (x)$ or $\log (x+1)$ or arcsine-square root $(x)]$ prior to analysis. The Tukey-Kramer Honestly Significant Difference (HSD) test was used for multiple means comparisons in a posteriori analyses. F- and p-values for MANOVA were from Wilks' Lambda calculations. A sequential Bonferroni correction (Rice 1989) was applied on a table-wise basis to p-values obtained in univariate analyses. We used $\mathrm{JMP}^{\circledR}$ or SAS Version 8 statistical software (SAS Institute) for all analyses and descriptive statistic calculations.

\section{RESULTS}

\section{Laboratory experiments}

Both larval presence and soluble nutrient type affected bacterial communities in microcosm water columns and leaf surfaces (Fig. 1, Table 1). Only bacterial cell densities in the water column were not significantly affected (Table 1). There was no evidence of interaction between nutrient and larval effects (Table 1). Larval presence reduced bacterial numbers and growth rates on leaf surfaces, and increased bacterial growth rates in the water column. Glucose in combination with inorganic nutrients was the most consistent stimulus for bacterial biomass, in terms of either leucine incorporation rates or cell numbers.

Glucose was the principal stimulus of bacterial production in natural treehole water samples (Fig. 2). The overall ANOVA was highly significant $(\mathrm{p}<0.0001$, treatment $\mathrm{df}=4$, error $\mathrm{df}=45$ ), and a posteriori means comparisons showed that glucose and combination treatments were the only treatments to increase bacterial production above control levels (Fig. 2). 


\section{Field Expt 1: Microbial responses}

Both multivariate and univariate analyses of water column microbial components indicated that time and larval presence had strong effects, but that any nutri- ent effects and interactions between main effects were undetectable (Table 2, Figs. 3, 4 \& 5). There were no significant block (tree) effects (data not shown) in any test. Bacterial abundance and production declined with time, but was unaffected by larval presence.

Table 1. Multivariate (MANOVA) and univariate hypothesis test results from Laboratory Expt 1. For univariate analyses, significant source effects at the $0.05 \alpha$-level after sequential Bonferroni correction are indicated with an asterisk

\begin{tabular}{|c|c|c|c|c|c|}
\hline \multirow[t]{2}{*}{$\begin{array}{l}\text { Multivariate } \\
\text { Source }\end{array}$} & \multirow[b]{2}{*}{ df (num,den) } & \multicolumn{2}{|c|}{ Water column } & \multicolumn{2}{|c|}{ Leaf surface } \\
\hline & & $F$-value & Prob $>F$ & $F$-value & Prob $>F$ \\
\hline Nutrient & 6,100 & 6.09 & $<0.0001$ & 4.46 & 0.0005 \\
\hline Larvae & 2,50 & 5.35 & 0.0085 & 57.12 & $<0.0001$ \\
\hline Nutrient $\times$ Larvae & 6,100 & 1.36 & 0.2391 & 1.43 & 0.2123 \\
\hline \multicolumn{6}{|l|}{ Univariate } \\
\hline Source & & $\begin{array}{l}\text { Abundance } \\
\left(\log \text { cells } \mathrm{ml}^{-1}\right)\end{array}$ & $\begin{array}{c}\text { Production } \\
\left(\log \mathrm{pmol}^{-1} \mathrm{~h}^{-1}\right)\end{array}$ & $\begin{array}{l}\text { Abundance } \\
\text { (log cells } \\
\text { per disc) }\end{array}$ & $\begin{array}{c}\text { Production } \\
(\log \text { pmol } \\
\left.\text { leucine per disc } \mathrm{h}^{-1}\right)\end{array}$ \\
\hline & df & $F$-value & $F$-value & $F$-value & $F$-value \\
\hline Nutrient & 3 & 1.98 & $10.82^{*}$ & $5.84^{*}$ & $3.52^{*}$ \\
\hline Larvae & 1 & 3.09 & $8.27^{*}$ & $112.13^{*}$ & $26.76^{*}$ \\
\hline Nutrient $\times$ Larvae & 3 & 0.25 & 2.81 & 1.50 & 2.34 \\
\hline Error & 53 & & & & \\
\hline
\end{tabular}

Table 2. Multivariate (MANOVA) and univariate hypothesis tests of water column microbial parameters from Field Expt 1. For univariate analyses, significant source effects at the $0.05 \alpha$-level after sequential Bonferroni correction are indicated with an asterisk

\begin{tabular}{|c|c|c|c|c|c|c|c|c|}
\hline $\begin{array}{l}\text { Multivariate } \\
\text { Source }\end{array}$ & \multicolumn{3}{|c|}{ df (num,dem) } & \multicolumn{3}{|c|}{$F$-value } & \multicolumn{2}{|c|}{ Prob $>F$} \\
\hline \multicolumn{2}{|l|}{ Time } & \multicolumn{2}{|r|}{14,18} & \multicolumn{3}{|c|}{8.35} & \multicolumn{2}{|c|}{$<0.0001$} \\
\hline Larvae & & \multicolumn{2}{|r|}{7,9} & \multicolumn{3}{|c|}{16.35} & \multicolumn{2}{|c|}{0.0002} \\
\hline Nutrient & & \multicolumn{2}{|r|}{7,9} & \multicolumn{3}{|c|}{1.00} & \multicolumn{2}{|c|}{0.4879} \\
\hline Time $\times$ Larvae & & \multicolumn{2}{|r|}{14,18} & \multicolumn{3}{|c|}{2.94} & \multicolumn{2}{|c|}{0.0168} \\
\hline Time × Nutrient & & \multicolumn{2}{|r|}{14,18} & \multicolumn{3}{|c|}{0.92} & \multicolumn{2}{|c|}{0.5538} \\
\hline Larvae × Nutrient & & \multicolumn{2}{|r|}{7,9} & \multicolumn{3}{|c|}{1.28} & \multicolumn{2}{|c|}{0.3582} \\
\hline Time $\times$ Larvae $\times$ Nutrient & & \multicolumn{2}{|r|}{14,18} & \multicolumn{3}{|c|}{0.49} & \multicolumn{2}{|c|}{0.9078} \\
\hline \multicolumn{9}{|l|}{ Univariate } \\
\hline \multirow[t]{2}{*}{ Source } & & $\begin{array}{l}\text { Flagellates } \\
\left(\log \text { no. } \mathrm{ml}^{-1}\right)\end{array}$ & $\begin{array}{c}\text { Cysts } \\
\left(\log \text { no. } \mathrm{ml}^{-1}\right)\end{array}$ & $\begin{array}{c}\text { Ciliates } \\
\left(\log \text { no. } \mathrm{ml}^{-1}\right)\end{array}$ & $\begin{array}{c}\text { Rotifers } \\
\left(\log \text { no. } \mathrm{ml}^{-1}\right)\end{array}$ & $\begin{array}{c}\text { Bacterial } \\
\text { abundance } \\
\left(\log \text { no. } \mathrm{ml}^{-1}\right)\end{array}$ & $\begin{array}{c}\text { Bacterial } \\
\text { production } \\
\text { (log pmol leu- } \\
\left.\text { cine } \mathrm{ml}^{-1} \mathrm{~h}^{-1}\right)\end{array}$ & $\begin{array}{l}\text { Protozoan } \\
\text { and rotifer } \\
\text { biovolume } \\
\left(\mu \mathrm{m}^{3} \mathrm{ml}^{-1}\right)\end{array}$ \\
\hline & df & $F$-value & $F$-value & $F$-value & $F$-value & $F$-value & $F$-value & $F$-value \\
\hline Time & 2 & $41.06^{*}$ & 3.3 & 4.01 & 0.96 & $17.41^{*}$ & $52.123^{*}$ & 5.2 \\
\hline Larvae & 1 & $142.23^{*}$ & $7.52^{*}$ & $48.57^{*}$ & $57.09^{*}$ & 0.85 & 0.90 & $10.75^{*}$ \\
\hline Nutrient & 1 & 1.18 & 0.00 & 0.22 & 0.04 & 0.08 & 1.16 & 4.01 \\
\hline Time × Larvae & 2 & $15.73^{*}$ & 1.18 & 1.31 & 1.35 & 4.58 & 2.83 & 2.40 \\
\hline Time $\times$ Nutrient & 2 & 0.26 & 0.27 & 3.49 & 0.01 & 4.00 & 0.20 & 3.20 \\
\hline Larvae $\times$ Nutrient & 1 & 0.83 & 1.57 & 3.16 & 0.55 & 1.36 & 0.03 & 6.69 \\
\hline Time $\times$ Larvae $\times$ Nutrient & 2 & 0.19 & 0.61 & 0.31 & 0.13 & 0.27 & 0.20 & 1.68 \\
\hline Error & 15 & & & & & & & \\
\hline
\end{tabular}


However, larval presence had pronounced and significant effects on abundance and total biovolume of protozoan groups present (Table 2, Figs. 4 \& 5). Larval presence reduced flagellate, ciliate, rotifer abundance

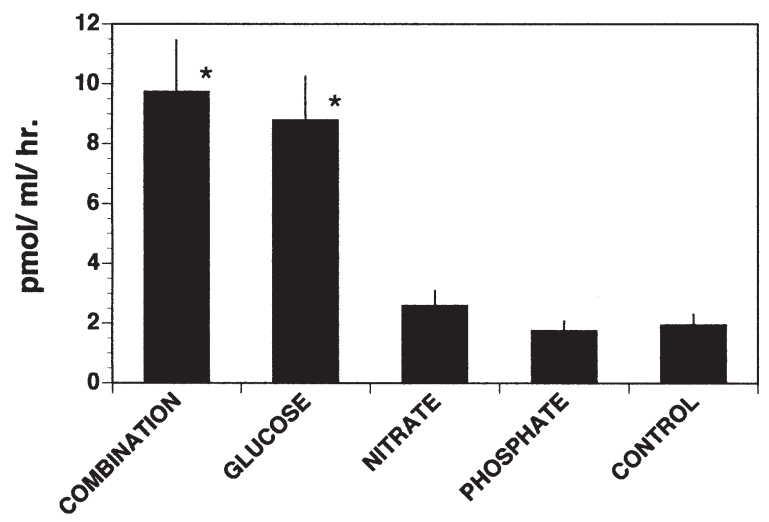

Fig. 2. Bacterial production (leucine incorporation rates) in natural treehole water in response to soluble nutrients. Combination $=$ glucose plus nitrate plus phosphate, Control $=$ deionized water. Values are mean $\pm \mathrm{SE}, \mathrm{n}=10$. *Values significantly different from the control mean based upon a posteriori

comparisons of all mean pairs (Tukey-Kramer HSD test)

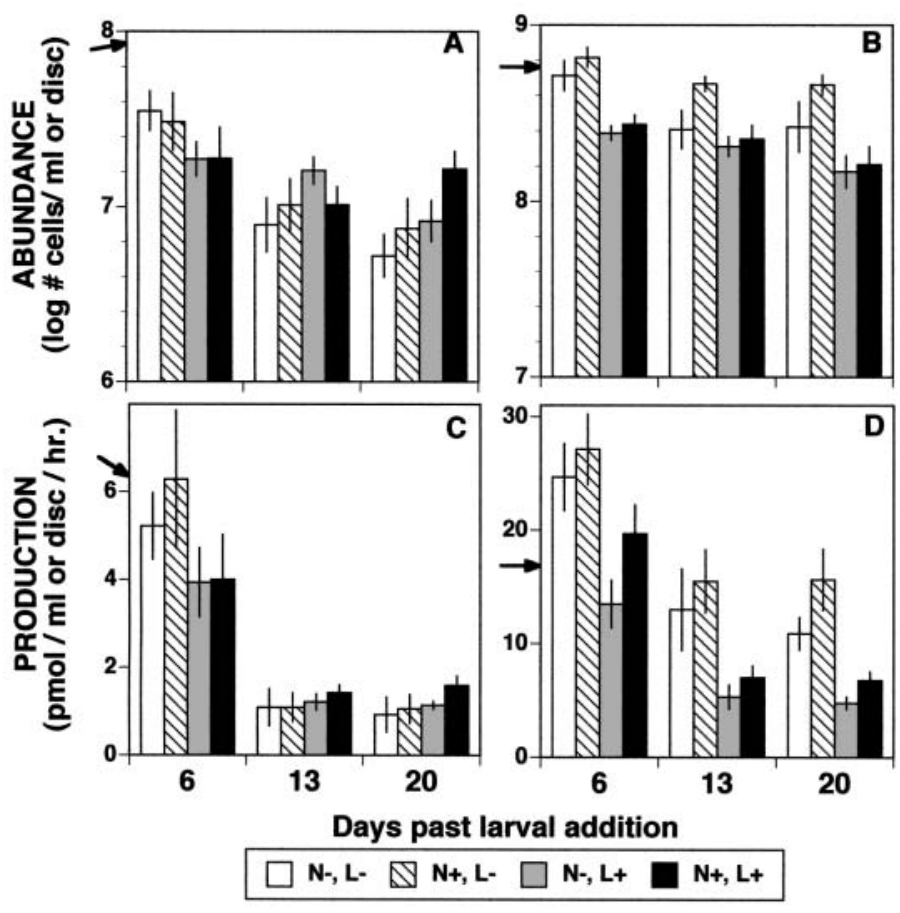

Fig. 3. Bacterial abundance (direct microscopic counts) and production (leucine incorporation rates) responses to larvae and soluble nutrient additions in Field Expt 1. (A,C) Water column; $(\mathrm{B}, \mathrm{D})$ leaf surface. Arrows on $y$-axes indicate initial levels (day of larval addition). $\mathrm{N}+=$ nutrients added, $\mathrm{N}-=$ no nutrients, $\mathrm{L}+=$ larvae present, $\mathrm{L}-=$ larvae absent. Values are mean $\pm \mathrm{SE}, \mathrm{n}=6$ and total biomass, and increased the number of protozoan cysts. A significant interaction between time and larvae in the MANOVA of water column microbial response suggests that larval grazing effects changed with time as illustrated by flagellate abundance trends (Fig. 4). Flagellate numbers declined by an order of magnitude between the day of larval addition and 1 wk after (Fig. 4), and generally declined during the course of the experiment. Conversely, the number of cysts increased, and small cysts in the same size classes as flagellates were more predominant in microcosms containing larvae (ANOVA of arcsine/square root-transformed percentage values, error $\mathrm{df}=60$, $\mathrm{p}<$ 0.0001 for larval main effect).

Leaf microbial responses, including general decay rate (mass loss) were also most strongly influenced by time and larval presence (Figs. 3 \& 6), and multivariate and univariate analyses (Table 3 ) were significant for these main effects. Based upon univariate analysis, nutrient addition significantly increased bacterial production; however, the nutrient effect in MANOVA was not significant ( $p=0.07$, Table 3 ). There were no significant interactions between the main effects (Table 3) and no significant block (tree) effects (results not shown). In contrast to the water column, leaf bacteria declined significantly in terms of abundance and biomass production rates when larvae were present. Ergosterol content in leaf material, expressed on a per disc (subsample or surface area) basis, declined significantly with time and in the presence of larvae (Fig. 6, Table 3). Although ergosterol declines indicated that fungal biomass associated with leaves was reduced in the presence of larvae in absolute terms, this reduction paralleled leaf disc mass loss as a function of larval presence (Fig. 6, Table 3). Ergosterol concentrations per dry weight of leaf material were not significantly affected by larvae (data and analysis not shown).

\section{Field Expts 1, 2, and 3: Mosquito biomass}

Nutrient additions enhanced mosquito survival rates and/or production in all field experiments (Fig. 7, Tables 4-6). In Field Expt 1, nutrient addition enhanced overall survival rates of mosquitoes, but had no effect on total mosquito biomass (Fig. 7A, Table 4). In Field Expt 2, the higher $(2 \times)$ nutrient treatment significantly enhanced total mosquito biomass (Fig. 7B, Table 5). Adult numbers and biomass were not significantly affected, largely because one low $(1 / 2 \times)$ nutrient microcosm produced 11 females. A grand total of 30 females and 71 males were collected from all microcosms over the $40 \mathrm{~d}$ of Field Expt 2. In Field Expt 3, the timing of nutrient addition significantly affected all measures of mosquito production (Fig. 7C, Table 6). 


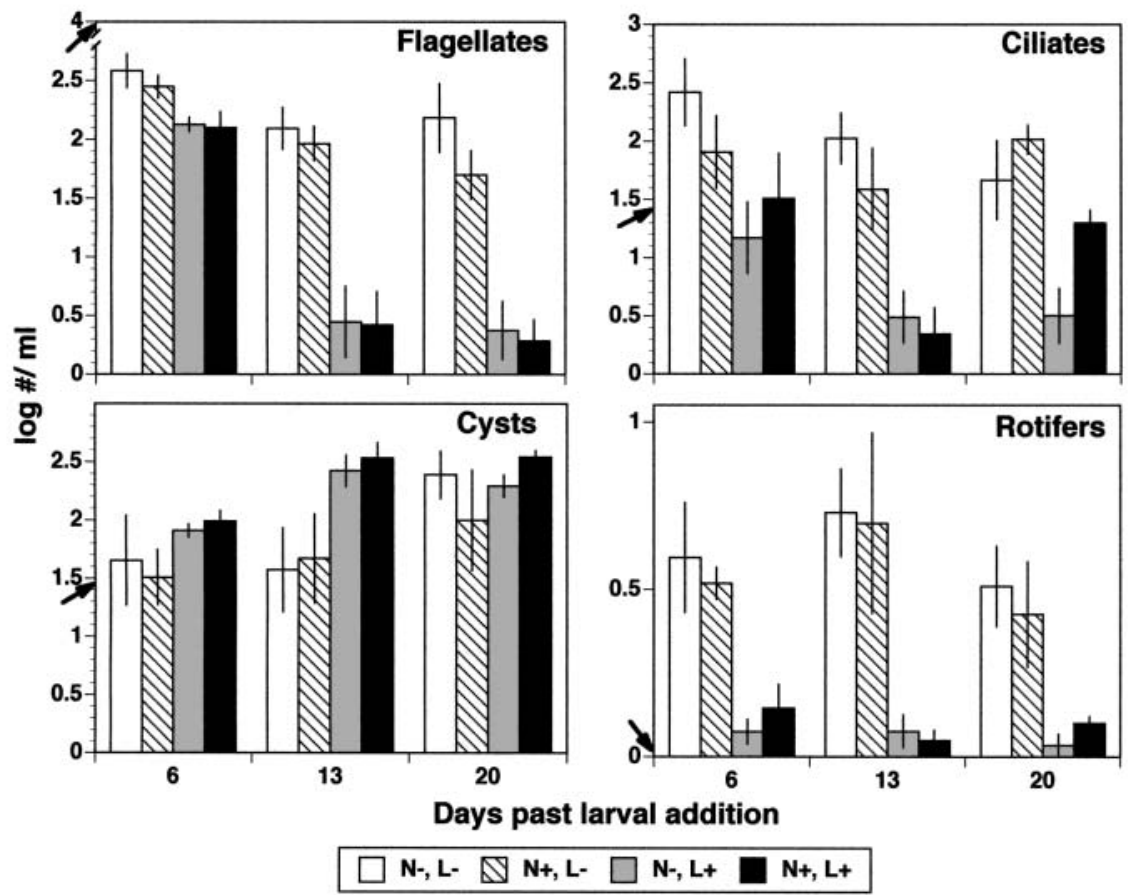

Fig. 4. Protozoan group abundance responses to larvae and soluble nutrient additions in Field Expt 1. Arrows on $y$-axes indicate initial levels (day of larval addition). $\mathrm{N}+=$ nutrients added, $\mathrm{N}-=$ no nutrients, $\mathrm{L}+=$ larvae present, $\mathrm{L}-=$ larvae absent. Values are mean $\pm \mathrm{SE}, \mathrm{n}=6$

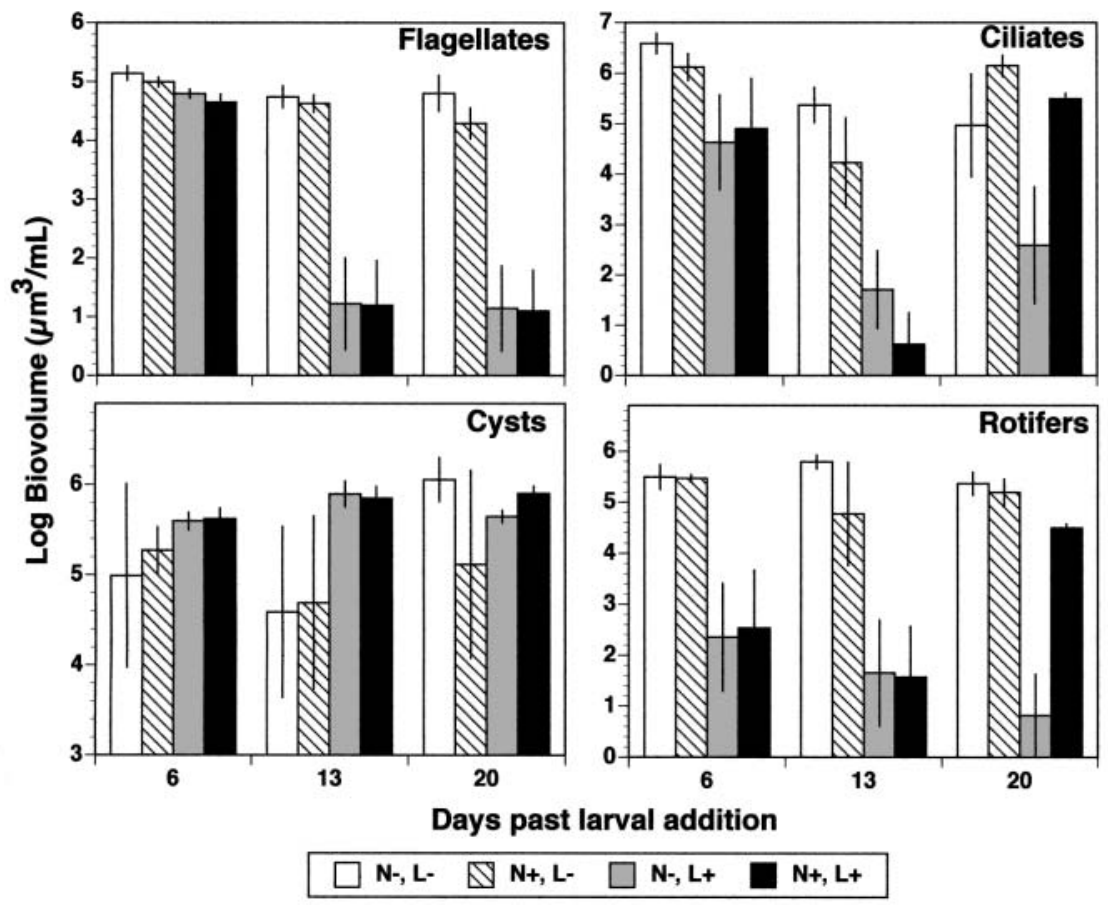

Fig. 5. Protozoan group biovolume responses to larvae and soluble nutrient additions in Field Expt 1. N+ = nutrients added, $\mathrm{N}-=$ no nutrients, $\mathrm{L}+=$ larvae present, $\mathrm{L}-=$ larvae absent. Values are mean $\pm \mathrm{SE}, \mathrm{n}=6$ 


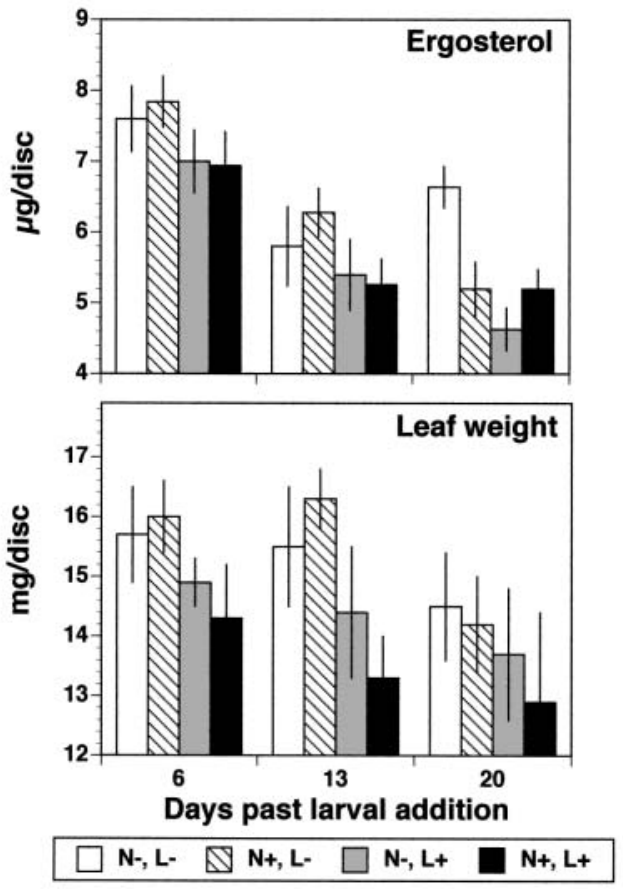

Fig. 6. Leaf ergosterol and leaf mass content responses to larvae and soluble nutrient additions in Field Exp. 1. N+ = nutrients added, $\mathrm{N}-=$ no nutrients, $\mathrm{L}+=$ larvae present, $\mathrm{L}-=$ larvae absent. Values are mean $\pm \mathrm{SE}, \mathrm{n}=6$
Additions of nutrients during the second week (Middle treatment) after larval addition were most effective in enhancing mosquito production. Over $40 \%$ of 173 males and 36 females collected from all microcosms emerged from the Middle treatment. There were no significant block (tree) effects in any test (data not shown).

\section{DISCUSSION}

This study showed that soluble nutrient additions stimulated bacterial production and mosquito production in simulated container-type habitats. This supports the concept that a principal role of stemflow in enhancement of Ochlerotatus triseriatus production from treeholes is to supply microbial growth-stimulating substrates. However, these nutrient additions in amounts typical of stemflow input were much less important in determining microbial biomass dynamics than the overriding impacts of larval grazing and background microbial succession processes. Interestingly, we found no strong evidence of interaction between larval grazing and nutrient addition, but did find that water column and leaf-surface microbial groups responded differently to the main treatments.

Table 3. Multivariate (MANOVA) and univariate hypothesis tests of leaf weight loss and leaf microbial parameters from Field Expt 1. For univariate analyses, significant source effects at the $0.05 \alpha$-level after sequential Bonferroni correction are indicated with an asterisk

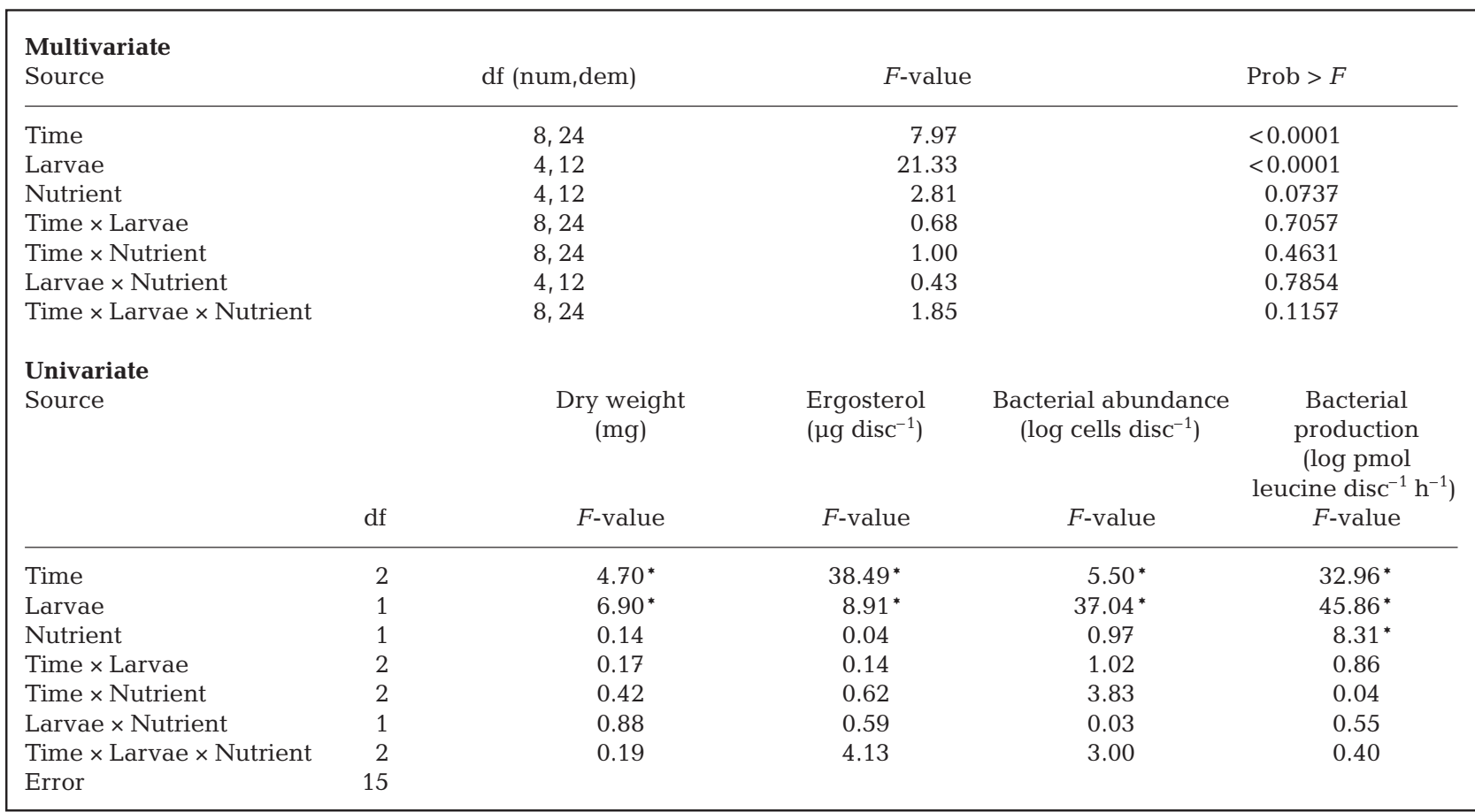



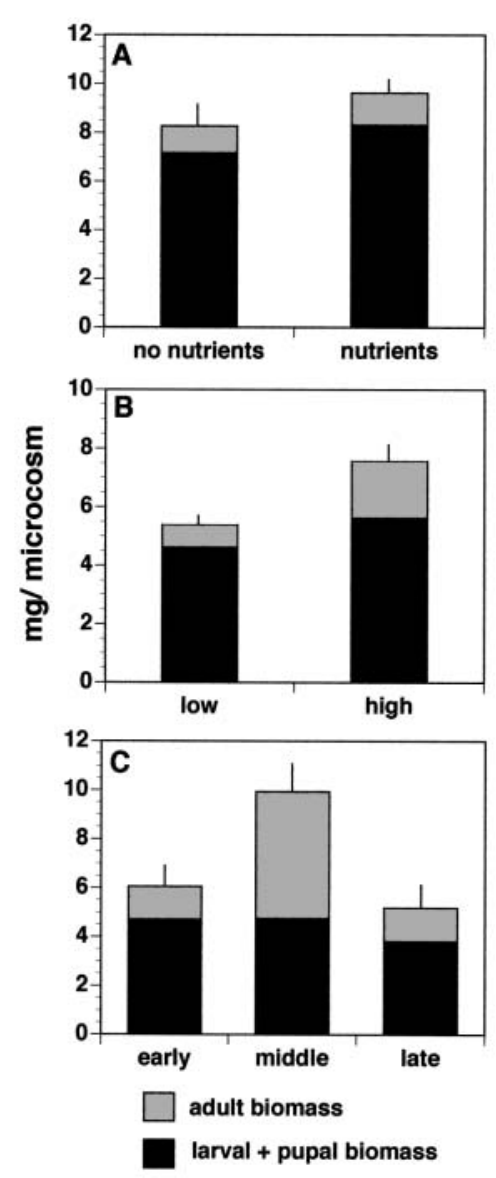

Fig. 7. Mosquito biomass responses to soluble nutrient additions in Field Expt 1 (A), 2 (B), and 3 (C). Values are mean $\pm \mathrm{SE}, \mathrm{n}=6$ to 8

\section{Larval grazing effects}

As a top level consumer capable of feeding on all lower trophic levels, Ochlerotatus triseriatus larvae had a profound effect on nearly all microbial components assayed in the this study and these feeding effects were not consistently negative. Water column bacteria responded differently than leaf-associated bacteria, showing less pronounced susceptibility to larval grazing and increased production rates in some cases. Although protozoans and rotifers generally declined in the presence of larvae, an increase in cyst formation showed the larval effect to be more than simple biomass harvesting. In contrast, declines in leaf-associated bacterial abundance and production, and leaf fungal biomass were consistently related to larval presence.

Most previous studies (Walker et al. 1991, CochranStafira \& von Ende 1998, Paradise \& Dunson 1998, Kaufman et al. 1999, 2001) of mosquito larval feeding on the bacterial component of container habitats have emphasized water column bacteria only. Results from laboratory and field experiments presented here mirror the variable bacterial responses to larval feeding observed in those studies. We also suggest that larvae may reduce some water column bacterial populations and stimulate others, resulting in undetectable effects on the composite of bacterial populations present at any one time. This is consistent with a shift in bacterial community structure as a response to larval feeding and likely reflects the decline of digestible bacteria and the increase of digestion-resistant populations (Cochran-Stafira \& von Ende 1998, Kaufman et al. 1999). This study is also noteworthy in that it shows that larvae may stimulate the growth rates of potential prey items under some conditions (Fig. 1), as has been shown frequently in zooplankton-phytoplankton interactions (Sterner \& Hessen 1994).

It might be expected that Ochlerotatus triseriatus larval feeding effects would enhance water column bacterial abundance because larvae reduced the numbers of bacterivorous protozoans and rotifers. However, our results are more comparable to freshwater planktonic systems with Daphnia as a top-level predator on both bacterial and protozoan components. Bacterial populations in these systems are often unable to increase after removal of protozoans because Daphnia feeding pressure on bacteria is maintained or intensified (Jürgens 1994, Langenheder \& Jürgens 2001). The only consistent responses in these systems have been a bacterial community shift to smaller cell size classes and, presumably, digestion-resistant forms (King et al. 1991, Jürgens 1994, Jürgens \& Montserrat-Sala 2000). We did not quantify bacterial morphotype changes in this study; however, we have observed increases in bacterial cell sizes related to the removal of larval $O$. trise-

Table 4. Multivariate (MANOVA) and univariate hypothesis tests of mosquito survival and total biomass from Field Expt 1. For univariate analyses, significant source effects at the $0.05 \alpha$-level after sequential Bonferroni correction are indicated with an asterisk

\begin{tabular}{|lccc|}
\hline $\begin{array}{l}\text { Multivariate } \\
\text { Source }\end{array}$ & df (num,dem) & $F$-value & Prob $>F$ \\
\hline Time & 4,28 & 13.72 & $<0.0001$ \\
Nutrient & 2,14 & 7.41 & 0.0064 \\
Time $\times$ Nutrient & 4,28 & 2.19 & 0.0955 \\
& & & \\
Univariate & & Survival & Total biomass \\
Source & df & $F$-value & $F$-value \\
& 2 & 2.71 & $23.98^{*}$ \\
Time & 1 & $13.82^{*}$ & 0.01 \\
Nutrient & 2 & 2.26 & 1.07 \\
Time $\times$ Nutrient & 15 & & \\
Error & & & \\
& & & \\
\hline
\end{tabular}


Table 5. Multivariate (MANOVA) and univariate hypothesis tests of mosquito survival and production from Field Expt 2. For univariate analyses, significant source effects at the $0.05 \alpha$-level after sequential Bonferroni correction are indicated with an asterisk

\begin{tabular}{|c|c|c|c|c|c|}
\hline $\begin{array}{l}\text { Multivariate } \\
\text { Source }\end{array}$ & df (num, dem) & $F$-value & Prob $>F$ & & \\
\hline Nutrient & 4,8 & 6.52 & 0.0123 & & \\
\hline $\begin{array}{l}\text { Univariate } \\
\text { Source }\end{array}$ & $\mathrm{df}$ & $\begin{array}{l}\text { Survival } \\
F \text {-value }\end{array}$ & $\begin{array}{c}\text { Total biomass } \\
F \text {-value }\end{array}$ & $\begin{array}{c}\text { Number of adults } \\
F \text {-value }\end{array}$ & $\begin{array}{c}\text { Total adult biomass } \\
F \text {-value }\end{array}$ \\
\hline $\begin{array}{l}\text { Nutrient } \\
\text { Error }\end{array}$ & $\begin{array}{r}1 \\
11\end{array}$ & 0.08 & $13.435^{*}$ & 4.71 & 2.38 \\
\hline
\end{tabular}

Table 6. Multivariate (MANOVA) and univariate hypothesis tests of mosquito survival and production from Field Experiment 3. For univariate analyses, significant source effects at the $0.05 \alpha$-level after sequential Bonferroni correction are indicated with an asterisk

\begin{tabular}{|c|c|c|c|c|c|}
\hline $\begin{array}{l}\text { Multivariate } \\
\text { Source }\end{array}$ & df (num, dem) & $F$-value & Prob $>F$ & & \\
\hline Nutrient & 8,18 & 4.04 & 0.0066 & & \\
\hline $\begin{array}{l}\text { Univariate } \\
\text { Source }\end{array}$ & df & $\begin{array}{l}\text { Survival } \\
F \text {-value }\end{array}$ & $\begin{array}{c}\text { Total biomass } \\
F \text {-value }\end{array}$ & $\begin{array}{c}\text { Number of adults } \\
F \text {-value }\end{array}$ & $\begin{array}{c}\text { Total adult biomass } \\
F \text {-value }\end{array}$ \\
\hline $\begin{array}{l}\text { Nutrient } \\
\text { Error }\end{array}$ & $\begin{array}{c}2 \\
12\end{array}$ & $8.81^{*}$ & $8.59^{*}$ & $7.07^{*}$ & $4.58^{*}$ \\
\hline
\end{tabular}

riatus from natural treeholes, suggesting direct and indirect interactions with the bacteria-protozoan food web (Kaufman et al. 2000).

In agreement with our previous studies (Kaufman et al. 1999, 2001), leaf surface bacteria showed consistently negative responses to larval grazing. Microorganisms associated with surfaces (leaf material and container walls) quantitatively represent the primary food resource for larvae in container habitats (Kaufman et al. 2001). These results support the idea that larval grazing of surfaces is intense enough to negate any compensatory bacterial community shifts or growth responses. This contrasts with findings in other detritivore/microbial prey systems where invertebrate grazing has usually been shown to stimulate microbial production (e.g. Lopez et al. 1977, Van De Bund et al. 1994, Graca et al. 2000).

Larval feeding effects on water column protozoa in this study agree with previous reports showing that protists are heavily grazed by larvae under most conditions (Kurihara 1983, Cochran-Stafira \& von Ende 1998, Paradise \& Dunson 1998, Eisenberg et al. 2000). The reduction of protozoan biomass in the presence of larvae could go far in explaining larval growth demands thought to be insufficiently met by bacterial biomass (Kaufman et al. 2001). However, protozoan turnover rates were not measured here and these coupled with larval predation rates would be necessary for estimates of protozoan contributions to larval growth. Non-encysted protozoan biomass generally declined or was stable in treatments free of larvae, so there was little evidence of rapid protozoan population growth in this study.

An unexpected result of this study was the high proportion of encysted protists in all treatments and the apparent stimulation of encystment by larvae. We did not attempt to identify the cysts, but size classes suggested that most flagellates and ciliates observed as active forms were also present as cysts. The majority of cysts observed were in the same size classes as flagellates, corresponding to a precipitous decline in flagellated populations at the start of the experiment (Fig. 4). Formation of cysts by planktonic protozoans is normally associated with declining nutritional conditions (Anderson 1988, Laybourn-Parry 1992). In this study, bacterial declines and/or community shifts due to lar- 
val feeding on bacteria may have effectively reduced resource abundance for bacterivorous protists and therefore accelerated the rate of cyst formation. Bacterial abundance and production also rapidly declined over this period, supporting the resource link hypothesis for cyst formation. Alternatively, cysts might represent a direct response to larval predation in their presumed greater resistance to digestion. To our knowledge, this has not been demonstrated in aquatic food webs, but resistance to digestion is clearly one function of pathogenic protozoan cysts in mammals (Anderson 1988).

Our results also present the first quantitative evidence of leaf fungal biomass harvest by larvae. In contrast to our previous investigation of this microbial component (Kaufman et al. 2001), larvae reduced levels of ergosterol concurrent with reducing leaf mass. Presumably, by browsing on leaf surfaces larvae abraded portions of the leaf matrix and consumed fungi as a result. This feeding activity is analogous to that of many aquatic detritivores which ingest decaying plant material in order to harvest the fungi within (Ingham 1992). Alternatively, larval activity may have stimulated leaf fungal decay activity that resulted in higher leaf mass loss when larvae were present. It has been shown that invertebrate grazing can stimulate fungal growth rates while reducing fungal biomass (Graca et al. 2000). An indirect enhancement of fungal activity might also have resulted from larval removal of leaf surface bacteria that compete with fungi for soluble resources.

Because ergosterol concentrations per leaf dry weight were unchanged by larvae, there is no evidence that larvae were able to selectively remove fungal biomass, as observed for some invertebrates that scrape decaying plant material (Newell \& Bärlocher 1993, Graca et al. 2000). Evidence for larval enhancement of leaf mass loss has been inconsistent and may depend on larval densities (Fish \& Carpenter 1982, Kaufman et al. 2001). Nonetheless, if any fungal biomass in leaf material is available to larval digestive processes, this resource would also help fill the nutritional gap between measured microbial biomass and larval demands (Kaufman et al. 2001).

\section{Nutrient effects on microbial biomass}

Our results indicate that labile organic carbon is likely the primary limitation to bacterial growth rates in Ochlerotatus triseriatus larval habitats, as has been shown to be the case in many aquatic habitats (Thomas 1997). Inorganic nutrients, principally N and P, may colimit some bacterial groups (e.g. those associated with leaf surfaces or those that employ oxidized forms of $\mathrm{N}$ as electron acceptors), but do not appear to stimulate bacteria without a concomitant source of DOC. It is unclear how these dynamics may change over the course of time in natural treeholes because levels of $\mathrm{N}$ and P fluctuate greatly (Walker et al. 1991) and there are little data on levels of labile DOC.

Inorganic nutrients such as $\mathrm{N}$ and $\mathrm{P}$ are known to limit microbial biomass and decomposition rates of leaf material in freshwater systems because most senescent leaf material has high initial ratios of $\mathrm{C}: \mathrm{N}$ and $\mathrm{C}: \mathrm{P} . \mathrm{N}$ and $\mathrm{P}$ from the overlying water act to stimulate fungal growth, which in turn increases leaf breakdown rates (Suberkropp 1995, Grattan \& Suberkropp 2001). Because we saw no significant nutrient effects on either ergosterol or leaf weight loss, it appears that nutrients at levels applied in Field Expt 1 did not greatly stimulate the leaf fungal populations. However, leaf-surface bacteria were stimulated by nutrients in our experiments, and differed from water column bacteria in response to DOC and $\mathrm{N}$ and $\mathrm{P}$ additions. The biofilm structure may have served to provide an already elevated level of DOC from leaf decay and would also present a potential diffusion barrier to water column inorganic nutrient pools (Costerton et al. 1995), thereby confounding effects of soluble nutrients introduced into the water column.

Although soluble nutrient additions were shown to stimulate water column bacterial production within $24 \mathrm{~h}$ in the laboratory experiments, nutrient additions during Field Expt 1 generally failed to elicit similar responses in bacterial growth rates. Part of the difference may be that, in the field experiment, responses were measured $48 \mathrm{~h}$ after nutrient additions, and glucose levels might have been depleted earlier within that time period. Production rates may have also been influenced by temperature regime differences. We monitored water temperatures in an extra microcosm throughout Field Expt 1. Although the overall mean temperature in the field microcosms was $21.5^{\circ} \mathrm{C}$, a value comparable to the $20^{\circ} \mathrm{C}$ constant temperature maintained in the laboratory, temperatures sometimes exceeded $29^{\circ} \mathrm{C}$.

\section{Mosquito response to nutrient additions}

Significant enhancement of leaf-associated bacterial production by nutrients points to a possible mechanism for increased mosquito survival in the $\mathrm{N}+$ treatments of Field Expt 1. The importance of leaf-associated microorganisms to Ochlerotatus triseriatus is well accepted but largely unmeasured (Walker \& Merritt 1988, Merritt et al. 1992, Leonard \& Juliano 1995). We have previously quantified larval feeding effects on leaf surface bacteria (Kaufman et al. 1999, 2001), but the current 
study provides the first evidence that stimulating the growth rate of leaf bacteria directly, compared to simply adding more leaf substrate, can enhance larval survival. Other factors are doubtless involved, but previous studies (Juliano \& Reminger 1992, Leonard \& Juliano 1995, Eisenberg et al. 2000) have demonstrated the positive behavioral and growth responses of larval stages to submerged surfaces. A potentially important component is container wall-associated microorganisms. We have shown that wall-associated bacteria are grazed as intensely as leaf-surface bacteria (Kaufman et al. 2001), but we have not investigated soluble nutrient effects on wall-associated microorganisms. In this study, nutrient stimulation of wall-associated microorganisms in conjunction with increased production of leaf-surface forms may also have enhanced mosquito production.

Despite increased mosquito survival in the N+ treatments, there was no difference in overall mosquito biomass production in Field Expt 1. By Day 20, there were approximately 6 more viable larvae per microcosm in the $\mathrm{N}+$ treatments. Consequently, larvae in the $\mathrm{N}-$ treatments tended to be larger than in $\mathrm{N}+$ treatments, and this likely resulted from less inter-specific competition for food and/or the added microbial production from decay of larval cadavers. Fourth instar Ochlerotatus triseriatus larvae can cannibalize first instars (Koenekoop \& Livdahl 1986), but this was highly unlikely in our study because all introduced individuals were from the same cohort and thus the necessary size discrepancy was absent. Recent work (Daugherty et al. 2000), however, demonstrates that insect cadavers can enhance mosquito production from container habitats, presumably via the microbial/detrital food web.

Mosquito production responses to nutrient additions in Field Expts 2 and 3 were more obvious than in Field Expt 1. Mosquito biomass was enhanced by doubling the input of nutrient levels supplied in preceding experiments. Also, by adding the same overall amount of nutrients as preceding experiments but in rapid succession during the second week of larval development, mosquito biomass, survival, and adult emergence were enhanced. These results mirrored previously established positive effects of stemflow on Ochleotatus triseriatus production, and suggest that soluble nutrient input from stemflow may be more important than flushing of inhibitory metabolites such as ammonium. In similar microcosms, concentrations of ammonium were within ranges found in natural treeholes (Kaufman et al. 1999); however, microcosms as described here are inherently 'younger', have less sediment build-up, and may not yet have accumulated other potentially toxic metabolites (e.g. hydrogen sulfide) compared to natural treeholes. It should also be noted that our additions of nutrients were based upon full replacement of container fluid by stemflow. While a typical stemflow event can flush and replace the water column several times over (Walker et al. 1991), our method of adding stemflow nutrients did not remove previously added nutrients. We are confident that labile carbon supplements did not accumulate between additions, except perhaps when added successively during Field Expt 3, because we measured soluble carbohydrate levels (M. Kaufman unpubl. data). However, we do not know how much $\mathrm{N}$ and $\mathrm{P}$ carried over. Thus, our nutrient additions may have added more available inorganic nutrients than would normally be found in a succession of stemflow events.

Although the effect of $2 \times$ nutrient input on mosquito production might be explained by presumed overall increases in microbial food sources, the effect of timing in the mosquito response to nutrients is not immediately clear. Adding nutrients consecutively during the second week had a more pronounced effect than giving a single pulse of $2 \times$ nutrient concentrations at weekly intervals (Fig. 7). It may be that development during the second week of the experiment, when most larvae would have been 4 th instar and males were beginning to pupate, was reaching a nutritional bottleneck due to decreasing microbial food resources and increasing larval demand (Kaufman et al. 2001). The bacterial production sustained by consecutive days of nutrient addition might simply have been a suitably high pulse at a critical time. Because a similar pulse during the third week, also during a time when larval demand would be high, did not result in the same effect, we can only assume that the gap between larval demand and microbial production at this time period was too great to be compensated for by a bacterial growth spurt.

We suggest, as did Daugherty et al. (2000), that nutrient 'pulse' inputs are a major characteristic of container habitats and that these supplemental nutrient pulses and the timing of their input can be as important as initial leaf input in determining mosquito production from container habitats. Although initial leaf input is critical for larvae (Carpenter 1983, Leonard \& Juliano 1995), this resource may degrade in quality rapidly (Macia \& Bradshaw 2000), thereby intensifying larval competition during development. Stemflow inputs alone are relatively unimportant in determining mosquito production compared to leaf material (Macia \& Bradshaw 2000), but can be important modifiers of leaf decay and mosquito performance (Carpenter 1982). Periodic supplements from stemflow or additional particulate input during leaf quality decline are probably critical in allowing continued development of larvae in treehole habitats. 
We have assumed in this study that nutrient addition effects on mosquito production are mediated through increases in microbial production. However, evidence exists that mosquito larvae can harvest DOC directly by drinking and subsequent absorption in the gut (Martin \& Edman 1991). Reported ingestion rates of radio-labeled, soluble glucose by larval Aedes aegypti, if applicable to Ochlerotatus triseriatus, would suggest that larvae could take up substantial quantities of dissolved glucose. However, calculation of drinking rates for $A$. aegypti larvae indicate that individual larvae imbibe only about $10 \mu \mathrm{l}$ of water per day (Aly 1985, Aly \& Dadd 1989), thereby making any harvest of soluble glucose in our experiment negligible. It has been shown that some aquatic invertebrates can absorb dissolved nutrients directly through the integument (Thomas 1997, Speas \& Duffy 1998), but this has not yet been demonstrated for mosquito larvae. Similarly, it has been suggested that $O$. triseriatus is limited by sodium in the treehole environment (Paradise \& Dunson 1998), but it has not been established if sodium limits larval growth directly or is mediated via a sodium limitation in the microbial food web. The ability of larvae to directly assimilate any soluble nutrients would further undermine the ability of current food web theory to describe this system because, in effect, a top-level consumer would be competing with the basal producers in the system for energy sources or cellular components.

\section{Summary and conclusions}

We have shown that Ochlerotatus triseriatus larvae can impact all lower trophic levels in container habitats and that soluble nutrient inputs can potentially modify these impacts and positively affect mosquito growth. O. triseriatus fed upon and reduced nearly all microbial components, but positive nutrient effects were most evident in the basal trophic level of leaf surface bacteria. Typical trophic cascade models of top-down and bottom-up effects (e.g. McQueen et al. 1986) that predict alternating positive and negative effects on trophic level sequences are not applicable in this case and simultaneous effects of nutrient and predation constraints must be considered (e.g. Batzer 1998). Food webs in most detritus-based systems are poorly understood (Rosemond et al. 2001), but the treehole system is comparable in some ways to planktonic lake systems dominated by large cladocerans. Daphnia feed upon both bacteria and their protozoan predators, having the general effect of reducing abundance of both groups and severely dampening bottom-up nutrient effects while also causing changes in microbial community composition (Jürgens 1994, Pace \& Cole 1996,
Langenheder \& Jürgens 2001). Food web models often ignore shifts in the composition of underlying trophic levels and these often determine biomass of trophic levels and energy transfer rates (Leibold et al. 1997, Cochran-Stafira \& von Ende 1998). In our system, we have observed shifts in bacterial communities (Kaufman et al. 1999) and protozoan growth forms (this study) in response to larval feeding and with time, suggesting that a different quality of microbial food resources accompanies a change in microbial abundance.

The implications of this study toward our understanding of mosquito production in container habitats encompass several aspects of the systems that are often ignored. First, the fundamental basis for bacterial production, and therefore resource-based competition by larvae, is likely labile organic carbon released from particulate organic substrates or found in rainwater/ stemflow input. In contrast to most other studied systems, $\mathrm{N}$ and $\mathrm{P}$ are probably secondary in controlling food resource production for invertebrate consumers. Many studies have shown this indirectly through the observed positive associations between larval development, leaf quantity, and leaf decay rate (e.g. Carpenter 1983), but few have actually quantified DOC release or measured bacterial growth (Walker et al. 1997, Kaufman et al. 2001). Second, substrate-associated bacterial biomass appears to be crucial for larvae, but to our knowledge, has been quantified only by our research group. We submit that bacteria on leaves and container surfaces provide the most constant food resource for larvae and, because of the large extracellular carbon content generally associated with attached bacterial forms (Costerton et al. 1995), are fundamental in the transfer to labile organic carbon to larvae biomass (see also Hall \& Meyer 1998). Third, the changes in microbial group composition or growth form induced by larval feeding against a backdrop of normal microbial successional changes and larval development arelikely to lead to accelerated resource depletion. Therefore, the timing of nutrient input relative to larval growth can be as critical as the quantity of input. These interactions are likely to be magnified in natural treehole systems where larval densities are generally much higher than in this study.

Acknowledgements. We gratefully acknowledge the technical assistance of Sandra Marsh, Heidi Volkhardt, Kim Luke, Tara Darcy, and Mary Kellogg. We also thank Alan Tessier for patient help with statistical interpretation and SAS, and thank 2 anonymous reviewers for their detailed, helpful comments. The research was supported by NIH Award AI21884 and conducted in collaboration with the Center for Microbial Ecology at Michigan State University. This is Kellogg Biological Station Contribution No. 973. 


\section{LITERATURE CITED}

Addicot JF (1974) Predation and prey community structure: an experimental study of the effect of mosquito larvae on the protozoan communities of pitcher plants. Ecology 55: 475-492

Addicot JF (1974) Predation and prey community structure: an experimental study of the effect of mosquito larvae on the protozoan communities of pitcher plants. Ecology 55: $475-492$

Aly C (1985) Feeding rate of larval Aedes vexans stimulated by food substrates. J Am Mosq Control Assoc 1:506-510

Aly C, Dadd R (1989) Drinking rate regulation in some freshwater mosquito larvae. Physiol Entomol 14:241-256

Anderson OR (1988) Comparative protozoology: ecology, physiology, life history. Springer-Verlag, New York

Batzer DP (1998) Trophic interactions among detritus, benthic midges, and predatory fish in a freshwater marsh. Ecology 79:1688-1698

Carpenter S (1982) Stemflow chemistry: effects on population dynamics of detritivorous mosquitoes in tree-hole ecosystems. Oecologia 53:1-6

Carpenter S (1983) Resource limitation of larval treehole mosquitoes subsisting on beech detritus. Ecology 64:219-223

Carpenter S (1984) Experimental test of the pupation window model for development of detritivorous insects. Ecol Model 23:257-264

Cochran-Stafira DL, von Ende CN (1998) Integrating bacteria into food webs: studies with Sarracenia purpurea inquilines. Ecology 79:880-898

Costerton JW, Lewandowski Z, Caldwell DE, Korber DR, Lappin-Scott HM (1995) Microbial biofilms. Annu Rev Microbiol 49:711-745

Daugherty MP, Alto BW, Juliano SA (2000) Invertebrate carcasses as a resource for competing Aedes albopictus and Aedes aegypti (Diptera: Culicidae). J Med Entomol 37: 364-372

Eisenberg JNS, Washburn JO, Schreiber SJ (2000) Generalist feeding behaviors of Aedes sierrensis larvae and their effects on protozoan populations. Ecology 81:921-935

Fish D, Carpenter SR (1982) Leaf litter and larval mosquito dynamics in tree-hole ecosystems. Ecology 63:283-288

Graca MA, Newell SY, Kneib RT (2000) Grazing rates of organic matter and living fungal biomass of decaying Spartina alterniflora by three species of salt-marsh invertebrates. Mar Biol 136:281-289

Grattan RM, Suberkropp K (2001) Effects of nutrient enrichment on yellow poplar leaf decomposition and fungal activity in streams. J N Am Benthol Soc 20:33-43

Hall ROJ, Meyer JL (1998) The trophic significance of bacteria in a detritus-based stream food web. Ecology 79: 1995-2012

Ingham RE (1992) Interactions between invertebrates and fungi. In: Carroll GC, Wicklow DT (eds) The fungal community. Dekker, New York, p 669-690

Juliano SA, Reminger L (1992) The relationship between vulnerability to predation and behavior of larval treehole mosquitoes: geographic and ontogenetic differences. Oikos 63:465-476

Jürgens K (1994) Impact of Daphnia on planktonic microbial food webs - a review. Mar Microb Food Webs 8:295-324

Jürgens K, Montserrat-Sala M (2000) Predation-mediated shifts in size distribution of microbial biomass and activity during detritus decomposition. Oikos 91:29-40

Kaufman MG, Walker ED, Smith TW, Merritt RW, Klug MJ (1999) The effects of larval mosquitoes Aedes triseriatus. and stemflow on microbial community dynamics in con- tainer habitats. Appl Environ Microbiol 65:2661-2673

Kaufman MG, Walker ED, Odelson DA, Klug MJ (2000) Microbial community ecology and insect nutrition. Am Entomol 46:173-184

Kaufman MG, Bland SN, Worthen ME, Walker ED, Klug MJ (2001) Bacterial and fungal biomass responses to feeding by larval Aedes triseriatus (Diptera: Culicidae). J Med Entomol 38:711-719

King CH, Sanders RW, Shotts KG Jr, Porter KG (1991) Differential survival of bacteria ingested by zooplankton from a stratified eutrophic lake. Limnol Oceanogr 36:829-845

Kirchman D (2001) Measuring bacterial biomass production and growth rates from leucine incorporation in natural aquatic environments. Methods Microbiol 30:227-237

Kitching R (2001) Food webs in phytotelmata: 'bottom-up' and 'top-down' explanations for community structure. Annu Rev Entomol 46:729-760

Koenekoop RK, Livdahl TP (1986) Cannibalism among Aedes triseriatus larvae. Ecol Entomol 11:111-114.

Kurihara Y (1983) The succession of aquatic dipterous larvae inhabiting bamboo phytotelmaata. In: Frank J, Lounibos L (eds) Phytotelmata: terrestrial plants as hosts for aquatic insect communities. Plexus Publishing, Medford, NJ, p 55-78

Langenheder S, Jürgens K (2001) Regulation of bacterial biomass and community structure by metazoan and protozoan predation. Limnol Oceanogr 46:121-134

Laybourn-Parry J (1992) Protozoan plankton ecology. Chapman \& Hall, London

Leibold MA, Chase JM, Shurin JB, Downing AL (1997) Species turnover and the regulation of trophic structure. Annu Rev Ecol Syst 28:467-494

Leonard PM, Juliano SA (1995) Effect of leaf litter and density on fitness and population performance of the treehole mosquito Aedes triseriatus. Ecol Entomol 20:125-136

Lopez GR, Levinton JS, Slobodkin LB (1977) The effect of grazing by the detritivore Orchestia grillus on Spartina litter and its associated microbial community. Oecologia 30: $111-127$

Macia A, Bradshaw WE (2000) Seasonal availability of resources and habitat degradation for the western treehole mosquito, Aedes sierrensis. Oecologia 125:55-65

Martin PJS, Edman JD (1991) Comparison of water ingestion between black flies (Simuliidae) and a mosquito (Aedes aegypti; Culicidae) using radio-labeled glucose. Hydrobiologia 209:227-234

McQueen, DJ, Post JR, Mills EL (1986). Trophic relationships in freshwater pelagic ecosystems. Can J Fish Aquat Sci 43: $1571-1581$

Mercer DR, Anderson JR (1994) Tannins in treehole habitats and their effects on Aedes sierrensis (Diptera: Culicidae) production and parasitism by Lambornella clarki (Ciliophora: Tetrahymenidae). J Med Entomol 31:159-167

Merritt R, Dadd R, Walker E (1992) Feeding behavior, natural food, and nutritional relationships of larval mosquitoes. Annu Rev Entomol 37:349-76

Newell SY, Bärlocher F (1993) Removal of fungal and total organic matter from decaying cordgrass leaves by shredder snails. J Exp Mar Biol Ecol 171:39-49

Pace ML, Cole JJ (1996) Regulation of bacteria by resources and predation tested in whole-lake experiments. Limnol Oceanogr 41:1448-1460

Paradise CJ, Dunson WA (1998) Effects of sodium concentration on Aedes triseriatus Diptera: Culicidae and microorganisms in treeholes. J Med Entomol 35:839-844

Porter KG (1996) Integrating the microbial loop and the classic food chain into a realistic planktonic food web. In: Polis 
GA, Winemiller KO (eds) Food webs: integration of patterns and dynamics. Chapman \& Hall, New York, p 51-59

Porter KG, Feig YS (1980) The use of DAPI for identifying and counting aquatic microflora. Limnol Oceanogr 25:943-948

Reinert JF (2000) New classification for the composite genus Aedes (Diptera, Culicidae, Aedini), elevation of the subgenus Ochlerotatus to generic rank, reclassification of the other subgenera, and notes on certain subgenera and species. J Am Mosq Cont Assoc 16:175-188

Rice WR (1989) Analyzing tables of statistical tests. Evolution 43:223-225

Rosemond AD, Pringle CM, Ramirez A, Paul MJ (2001) A test of top-down and bottom-up control in a detritus-based food web. Ecology 82:2279-2293

Smith DC, Azam F (1992) A simple, economical method for measuring bacterial protein synthesis in seawater using 3H-leucine. Mar Microb Food Webs 6:107-114

Speas DW, Duffy WG (1998) Uptake of dissolved organic carbon (DOC) by Daphnia pulex. J Freshw Ecol 13:457-463.

Sterner RW, Hessen DO (1994) Algal nutrient limitation and nutrition of aquatic herbivores. Annu Rev Ecol Syst 25: $1-29$

Suberkropp K (1995) The influence of nutrients on fungal growth, production, and sporulation during leaf breakdown in streams. Can J Bot 73(Suppl 1):S1361-S1369

Suberkropp K, Weyers H (1996) Application of fungal and bacterial production methodologies to decomposing leaves in streams. Appl Environ Microbiol 62:1610-1615

Thomas JD (1997) The role of dissolved organic matter, par-

Editorial responsibility: John Dolan, Villefranche-sur-Mer, France ticularly free amino acids and humic substances, in freshwater ecosystems. Freshw Biol 38:1-36

Van De Bund WJ, Goedkoop W, Johnson RK (1994) Effects of deposit-feeder activity on bacterial production and abundance in profundal lake sediment. J N Am Benthol Soc 13: 532-539

Walker E, Merritt R (1988) The significance of leaf detritus to mosquito (Diptera: Culicidae) productivity from treeholes. Environ Entomol 17:199-206

Walker E, Merritt R (1991) Behavior of larval Aedes triseriatus (Diptera: Culicidae). J Med Entomol 28:581-589

Walker ED, Lawson DL, Merritt RW, Morgan WT, Klug MJ (1991) Nutrient dynamics, bacterial populations, and mosquito productivity in tree hole ecosystems and microcosms. Ecology 72:1529-1546

Walker ED, Kaufman MG, Ayres MP, Riedel MH, Merritt RW (1997) Effect of variation in quality of leaf detritus on growth of the eastern tree hole mosquito Aedes triseriatus Diptera: Culicidae. Can J Zool 75:706-718

Washburn JO, Gross ME, Mercer DR, Anderson JR (1988) Predator-induced trophic shift of a free-living ciliate: parasitism of mosquito larvae by their prey. Science 240:1193-1195

Wetzel RG (1995) Death, detritus, and energy flow in aquatic ecosystems. Freshw Biol 33:83-89

Wetzel RG, Likens GE (1991) Limnological analyses. Springer-Verlag, New York, p 139-166

Yanoviak SP (1999) Effects of leaf litter species on macroinvertebrate community properties and mosquito yield in neotropical tree hole microcosms. Oecologia 120:147-155

Submitted: February 1, 2002; Accepted: August 1, 2002 Proofs received from author(s): August 27, 2002 